\title{
A novel mutation (c.T3816 > C) in the androgen receptor gene in a 46,XY female patient with androgen insensitivity syndrome
}

\author{
Nowa mutacja (c.T3816 > C) w genie receptora androgenowego u pacjentki \\ 46,XY z zespołem niewrażliwości na androgeny

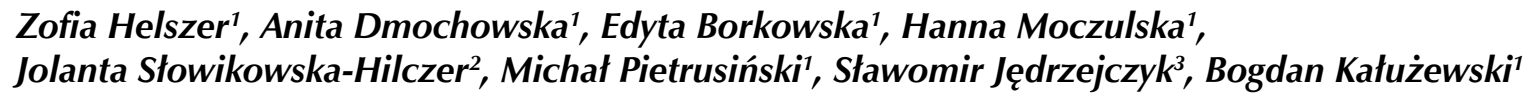 \\ ${ }^{1}$ Department of Medical Genetics, Medical University of Lodz, Poland \\ ${ }^{2}$ Department of Andrology and Reproductive Endocrinology, Medical University of Lodz, Poland \\ ${ }^{3}$ Clinic of Rapid Diagnostics and Gynaecological Therapy, Medical University of Lodz, Poland
}

\begin{abstract}
Introduction: Androgen receptor (AR) gene mutations are the most frequent cause of 46,XY disorders of sex development (DSD), and are associated with a variety of phenotypes ranging from phenotypic women (Complete Androgen Insensitivity Syndrome or CAIS) to milder degrees of undervirilisation (Partial Androgen Insensitivity Syndrome or PAIS) or men with infertility only (Mild Androgen Insensitivity Syndrome or MAIS).

In this paper, we present the results of clinical, endocrine and molecular trials in a patient hospitalised because of primary amenorrhoea with typical phenotype of CAIS.

Material and methods: The main objective of this study was to determine the molecular cause of androgen insensitivity syndrome in a 46,XY female patient. Molecular analysis of the AR gene was conducted using MSSCP (Multitemperature Single Strand Conformation Polymorphism) and sequencing methods.

Results: MSSCP analysis showed changes in electrophoretic mobility in exon 8 of the $A R$ gene. Sequencing analysis revealed a missense mutation which has not been previously described. This is a c.T3816 > C transition mutation which causes a S901P substitution in the amino acid chain (based on the latest NCBI reference sequence NM 000044.2).

Conclusions: The identified c.T3816 > C mutation in AR gene provides further evidence for the correlation between specific AR mutations and phenotype corresponding to androgen insensitivity. (Endokrynol Pol 2013; 64 (5): 398-402)
\end{abstract}

Key words: disorders of sex development (DSD), androgen insensitivity syndrome (AIS), androgen receptor, missense mutation

\section{Streszczenie}

Wstęp: Mutacje w genie receptora androgenowego (AR, Androgen Receptor) są najczęstszą przyczyną zaburzeń różnicowania płci (DSD, Disorders of Sex Development) powodującą zespół niewrażliwości na androgeny (AIS, Androgen Insensitivity Syndrome). Chorzy wykazują znaczną różnorodność fenotypu: od żeńskiego (CAIS, Complete Androgen Insensitivity syndrome) przez niecałkowicie męski (PAIS, Partial Androgen Insensitivity Syndrome) aż do prawidłowo zbudowanych niepłodnych mężczyzn (MAIS, Mild Androgen Insensitivity Syndrome). W pracy przedstawiamy wyniki badań klinicznych, endokrynologicznych oraz molekularnych pacjentki hospitalizowanej z powodu pierwotnego braku miesiączki z typowymi cechami zespołu niewrażliwości na androgeny.

Materiał i metody: Celem badań było określenie podłoża molekularnego zespołu niewrażliwości na androgeny u kobiety 46,XY. Przeprowadzono analizę molekularną genu AR z zastosowaniem metod: MSSCP (Multitemperature Single Strand Conformation Polymorphism) oraz sekwencjonowania.

Wyniki: Analiza polimorfizmu konformacji pojedynczych nici DNA w gradiencie temperatury wykazała zmianę ruchliwości elektroforetycznej w egzonie 8 genu $A R$. W wyniku sekwencjonowania egzonu 8 wykryto mutację punktową typu missens. Mutacja, dotychczas nie opisywana, ma charakter tranzycji c.T3816 > C i powoduje zmianę S901P w łańcuchu aminokwasowym (w oparciu o najnowszą sekwencję referencyjną NCBI, NM 000044.2).

Wnioski: Stwierdzenie nowej mutacji, c.T3816 > C w genie AR jest kolejnym dowodem potwierdzającym związek mutacji AR z fenotypem zespołu niewrażliwości na androgeny. (Endokrynol Pol 2013; 64 (5): 398-402)

Słowa kluczowe: zaburzenia rozwoju płci, zespół niewrażliwości na androgeny, receptor androgenowy, mutacja missens 


\section{Introduction}

Androgen receptor (AR) gene mutations are the most frequent cause of 46,XY disorders of sex development (DSD), and are associated with a variety of phenotypes, ranging from phenotypic women (CAIS) to milder degrees of undervirilisation (PAIS) or men with only infertility (MAIS) [1-3].

The androgen receptor is an intracellular receptor ligand that functions as a transcription factor. The protein is composed of four different functional domains responsible for gene transactivation (NTD, N-terminal domain), DNA binding (DBD, DNA-binding domain), receptor transport to the nucleus and hormone binding (LBD, C-terminal ligand-binding domain)[4]. The AR has two main activation functions: constitutive (AF-1) in NTD, and hormone-dependent (AF-2) in the LBD. AR AF-2 interactions with the AR-NTD (AR N/C terminal interactions) are essential for the transactivational properties of the receptor [5].

The gene encoding the androgen receptor is localised in region q11-12 of the $X$ chromosome. It consists of eight exons. Exon 1 encodes the NTD domain, exons 2 and 3 encode the DBD domain, exons 3 and 4 encode hinge region or bipartite nuclear localisation, and exons 4-8 encode the LBD domain [6]. More than 800 different mutations in the $A R$ gene have been identified in people with androgen insensitivity syndrome and most $A R$ mutations are localised in the LBD and are available in the mutations database $[1,7]$. The steroid-binding domain contains residues between amino acids 670 and 919 of the AR and is encoded by a part of exon 4 and exons $5-8$. The region shares $50 \%$ homology with respective regions of other steroid receptors. Its crystal structure shows that the LBD consists of nine a-helices, two $3_{10}$ helices, described as helices $1-12$, and four short b-strands and two antiparallel b-sheets. The main function of this domain is highly specific binding of androgens. The correct structure is needed to convert an inactive form to an active one of the receptor upon binding of androgens. It is also involved in receptor dimerisation and transcriptional regulation $[8,9]$.

LBD mutations include a majority of amino acid residues that line the AR ligand-binding pocket [10]. However, many other mutations may have an indirect impact on the structure of the cofactor-binding pocket and binding of the ligand. Disrupted binding of the ligand may also affect the structure of the cofactor-binding groove, and inhibit N/C and cofactor interaction. Furthermore, binding of proteins to the cofactor-binding groove might affect binding of the ligand [11]. There is evidence indicating that disrupted N/C interaction can serve as a mechanism for AIS also in cases where ligand binding is normal [12-14].

Mutations of this domain lead to AR disorders responsible for androgen insensitivity syndrome or contribute to an increased risk of the development of prostate cancer $[15,16]$.

In this study, we describe a $46, X Y$ phenotypically female patient with all of the characteristics of CAIS in which a novel mutation in exon 8 of the $A R$ gene in the LBD domain is responsible for the disease.

\section{Case description and methods}

The patient was referred to the Genetic Outpatients Clinic at the age of 21 due to primary amenorrhoea. The patient's height was $171 \mathrm{~cm}$; delayed puberty: A-0, P-0, Th-1, amenorrhoea, normal structure of external sexual organs was found on physical examination. Family history: two younger sisters of the patient menstruate normally, however primary amenorrhoea in a daughter of one of the mother's sisters was observed. We did not have the possibility to perform the test.

The gynaecological examination confirmed female external sexual organs: no pubic and axillary hair, labia majora underdevelopment, labia minora normal. Clitoris not enlarged with normal structure. Vaginal recess ca. $3 \mathrm{~cm}$. long, blind-ended. Hormonal studies showed high testosterone level, low gonadotropin levels and oestradiol within the normal female ranges. Cytogenetic examination revealed a 46,XY karyotype both in lymphocytes and skin fibroblasts. The material derived from skin biopsy was cultured in situ for archiving the patient's cells in the tissue bank. The patient remained under medical supervision of the Genetic Outpatients Clinic; however, surgery was not performed despite recommended gonadectomy due to lack of patient consent for the treatment.

Ultrasound examination of the pelvis revealed an oval hypoechogenic cyst $(30 \times 16 \mathrm{~mm})$ in the left inguinal area within the true pelvis, and a non-homogenous double cystic structure in the right inguinal area. CT examination of the pelvis: an oval, solid structure, 3-2.8 $\mathrm{cm}$, visible medially from the vascular bundle in the left inguinal area. No uterus in the minor pelvis. Ultrasound test result was one of the arguments for carrying out diagnostic laparoscopy.

Physical examination of the patient at the age of 30 revealed puberty stages: A- 0, P- 1 , Th-III; palpation and ultrasound examinations confirmed the presence of a dysplastic gonad within the left inguinal canal. Gonadectomy was recommended again. The patient underwent gonadectomy at the age of 34 (Fig. 1AB).

Histopathological examination of the gonads: both gonads have similar histopathological structures with 


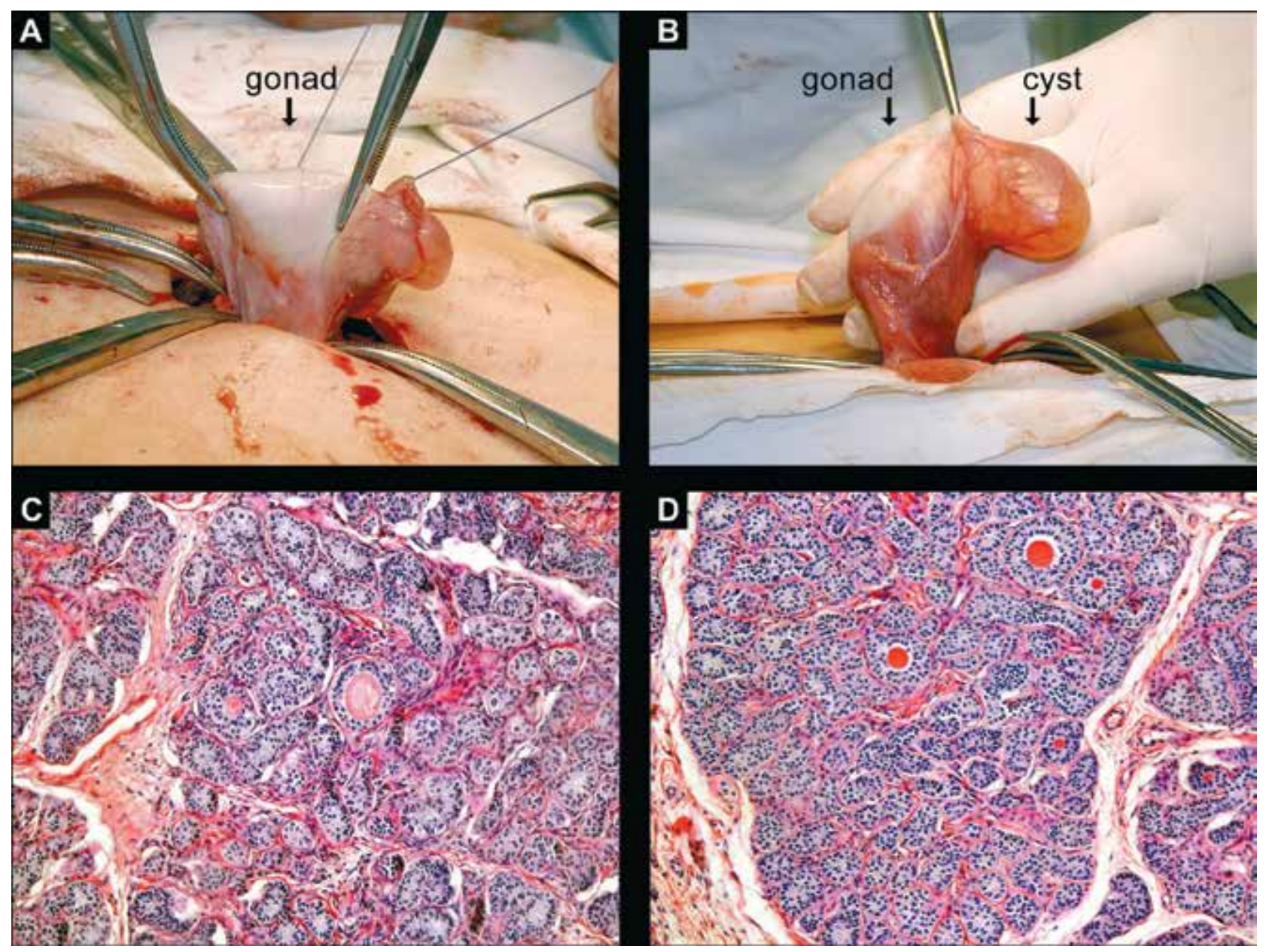

Figure 1. Gonadectomy and gonadal histopathology: A, C. right gonad; B, D. left gonad

Rycina 1. Gonadektomia i histopatologia gonad: A, C. gonada prawa; B, D. gonada lewa

prevailing Sertoli cell nodules and benign Sertoli cell tumours with single gonocytes. They are separated by a hyalinised stroma with scarce Leydig cells in intertubular spaces. Hyaline bodies are visible in the tubular lumens of either gonad. The microscopic picture on the left side reveals some texture of the uterine tube with extended lumen and wall fibrosis. Malignancy of the tumours was not found. The WHO recommendations, suggesting a differentiation between Sertoli cell nodules and Sertoli cell tumours, turned out to be totally impractical (Fig. 1CD).

\section{Molecular analysis}

Genomic DNA of the patient and a healthy person (control) was automatically isolated from peripheral blood lymphocytes (MagNa Pure Compact, Roche).

Exons from 2 to 8 of the $A R$ gene were amplified with PCR using specific primers [17]. PCR products were screened with the MSSCP method and/or direct sequencing (Macrogen's sequencing service, Korea).

\section{Results and discussion}

Clinical and histopathological findings and diagnostic laparotomy was carried out in the framework of the differential diagnostics of CAIS. Results of molecular analysis decisively confirmed the preliminary diagnosis.

Single strand conformation polymorphism analysis of the PCR products of the AR gene revealed changes in electrophoretic mobility in exon 8 , which could suggest the occurrence of a mutation. Sequencing of exon 8 confirmed a missense mutation in position c.T3816 $>C$. This transition mutation results in a change of serine into proline at position 901 of the amino acid chain (S901P) (Fig. 2AB). This mutation has not been previously described in the literature.

The mutation is localised in the LBD domain of the AR within helix 12 of the AF-2 core domain. In line with the crystal structure of the AR, Ser 901 is the last amino acid residue of the AF-2 core domain of the activation domain (AD) located in helix 12 in the 


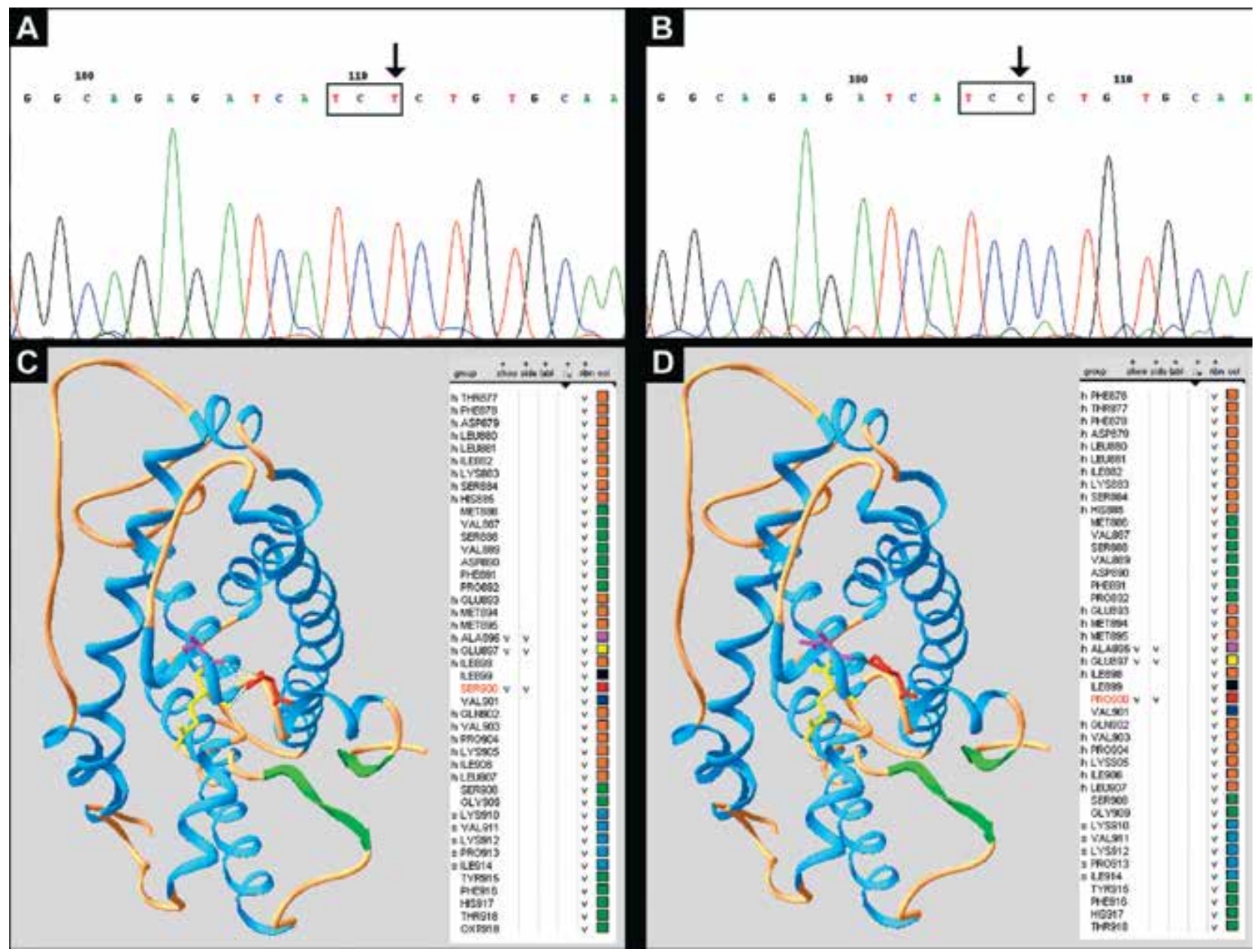

Figure 2. DNA sequence of exon 8 of the AR gene. A. c. T3816 > C mutation; B. normal sequence (control). A three-dimensional model of human androgen receptor ligand binding domain (with Swiss — PdbViewer program v 4.0.1): C. wildtype, B. mutant

Rycina 2. Sekwencja egzonu 8 genu AR. A. mutacja c. T3816 > C; B. sekwencja prawidłowa (kontrola). Struktura przestrzenna domeny LBD (w oparciu o program Swiss - PdbViewer v 4.0.1): C. struktura prawidtowa, B. mutacja c. T3816 > C

C-terminal end of the LBD [18]. This short C-terminal sequence is conserved in the family of nuclear receptors and is essential for their normal functioning. To investigate the role of Ser 901 in AR LBD structure, we used a three-dimensional model of human androgen receptor ligand binding domain. This was generated on the basis of the known atomic structure of AR LBD available from Protein Data Bank with accession code 1e3g [19]. The model of androgen receptor mutant structure was generated by modifying the AR LBD at the position where the mutation occurred. The stereo representation was rendered and final figures were drawn with Swiss -PdbViewer program v 4.0.1.

S901 residue is highly conserved in the structure of androgen receptors among species. This residue is located in the loop between two $\alpha$-helices and forms a bridge with one of these two secondary structures of AR LBD.

In wild type of AR LBD (Fig. 2C) the Ser901 residue forms two strong hydrogen bonds (green dotted line) with alanine (Ala897 — pink colour) and one strong hydrogen bond with glutamic acid (Glu898 - yellow colour) of one $\alpha$-helix secondary structure (light-blue colour). Both Ala897 and Glu898 residues are conserved among AR LBD sequences. This pattern of Ala897Glu898-Ser901 conservation and hydrogen bonds formation suggests that the conformation of protein fold in this region is crucial for ligand binding domain stability and activity.

In the case of S901P substitution in mutant AR LBD (Fig. 2D), there is only one hydrogen bond with alanine (Ala897 - pink colour) of $\alpha$-helix secondary structure (light-blue colour) and no hydrogen bond with glutamic acid (Glu898). Additionally, substitution of serine by proline at 901 position leads to a steric clash (black dotted line) that violates basic atomic properties. The bond energy of the misfolded protein at this position is not at a minimum. The possible result is a misfolding of the ligand binding domain and thus diminished binding affinity. 
It has been shown that the AF-2 AD plays an important role in the N/C interaction. Disrupted binding of the ligand may also affect the structure of the cofactorbinding groove and inhibit N/C interaction and cofactor interaction $[20,21]$.

The diagnosis of complete androgen insensitivity syndrome is an indication for prophylactic removal of the gonad because of increased risk of cancer. However, the issue of gonadectomy is controversial. Optimal timing and necessity for removal of testes have been debated. Some have argued that the true risk for malignant transformation of the gonads is small and have suggested postpubertal gonad biopsy as opposed to removal [22].

Histopathological examination of gonads in our patient revealed hyperplasia of Sertoli cells in the form of nodules (target Sertoli nodule) and/or benign tumours of the Sertoli cells (Sertoli cell tumour). Malignancy of the tumours was not found. This is consistent with the opinion among physicians that the risk of malignancy in androgen receptor insensitivity syndrome is considerably lower than with other intersex disorders, and can occur at a later age $[23,24]$.

The identified mutation in $A R$ gene is novel and provides further evidence for the correlation between specific $A R$ mutations and phenotype corresponding to androgen insensitivity syndrome.

\section{References}

1. Gottlieb B, Beitel LK, Nadatrajach A et al. The androgen receptor gene mutations database. Hum Mutat 2012; 5: 887-894.

2. Jääskelainen J. Molecular biology of androgen insensitivity. Mol Cell Endocrinol 2012; 352: 4-12

3. Lee PA, Houk CP, Ahmed SF et al. Consensus statement on management of intersex disorders. International Consensus Conference on Intersex. Pediatrics 2006; 118: 488-500.

4. Ikonen T, Palvimo JJ, Janne OA. Interaction between the amino- and carboxyl-terminal regions of the rat androgen receptor modulates transcriptional activity and is influenced by nuclear receptor coactivators. J Biol Chem 1997; 272: 29821-29828.

5. Berrevoets CA, Doesburg P, Steketee Ket al. Functional interactions of the AF-2 activation domain core region of the human androgen receptor with the amino-terminal domain and with the transcriptional coactivator TIF2 (transcriptional intermediary factor 2). Mol Endocrinol 1998; 12: 1172-1183.
6. Melo KFS, Mendonca BB, Billerbeck AEC et al. Clinical, hormonal, behavioral and genetic characteristics of androgen insensitivity syndrome in a Brazilian cohort: Five novel mutations in the androgen receptor gene. J Clin Endocrinol Metab 2003; 88: 3241-3250.

7. Gottlieb B, Beitel LK, Wu JH et al. The androgen receptor gene mutations database (ARDB): 2004 update. Human Mutation 2004; 23: 527-533.

8. Tahiri B, Auzou G, Nicolas JC et al. Participation of critical residues from the extreme $\mathrm{C}$-terminal end of the human receptor in the ligand binding function. Biochemistry 2001; 40: 8431-8437.

9. Brinkmann, A.O. Molecular basis of androgen insensitivity. Mo. Cell Endocrinol 2001; 179: 105-109.

10. Gottlieb B, Beitel LK, Trifiro MA. Variable expressivity and mutation database. Hum Mutat 2001b; 17: 382-388.

11. Dubbink HJ, Hersmus R, Pike AC et al. Androgen receptor ligandbinding domain interaction and nuclear receptor specificity of FXXLF and LXXLL motifs as determined by L/F swapping. Mol Endocrinol 2006; 20: 1742-1755.

12. Ghali SA, Gottlieb B, Lumbroso R et al. The use of androgen receptor amino/carboxyl-terminal interaction assays to investigate androgen receptor gene mutations in subjects with varying degrees of androgen insensitivity. J Clin Endocrinol Metab 2003; 88: 2185-2193.

13. Thompson J, Saatcioglu F, Janne OA et al. Disrupted amino-and carboxylterminal interactions of the androgen receptor are linked to androgen insensitivity. Mol Endocrinol 2001; 15: 923-935.

14. Jaaskelainen J, Deeb A, Schwabe JW et al. Human androgen receptor gene ligand-binding-domain mutations leading to disrupted interaction between the N- and C-terminal domains. J Mol Endocrinol 2006; 36: 361-368.

15. Gelman EP. Molecular biology of the androgen receptor. J Clin Oncol 2002; 20: 3001-3015.

16. Matias PM, Donner P, Coelho R et al. Structural evidence for ligand specificity in the binding domain of the human androgen receptor: implications for pathogenic gene mutations. J Biol Chem 2000; 275: 26164-26171.

17. Turek-Plewa J, Eckersdorf-Mastalerz MD, Kałużewski B et al. A mutation c. C2812T in the androgen receptor gene resulting in Pro817Leu substitution may affect dimerization of the androgen receptor and result in androgen insensitivity syndrome. Fertil Steril 2006; 85: 1822-1825.

18. Wurtz JM, Bourguet W, Renaud JP et al. A canonical structure for the ligand-binding domain of nuclear receptors. Nat Struct Biol 1996; 3: 206

19. Guex N, Peitsch MC. SWISS-MODEL and the Swiss-PdbViewer: An environment for comparative protein modeling. Elektrophoresis 1997; 18: 2714-2723.

20. Ghali SA, Gottlieb B, Lumbroso R et al. The use of androgen receptor amino/carboxyl-terminal interaction assays to investigate androgen receptor gene mutations in subjects with varying degrees of androgen insensitivity. J Clin Endocrinol Metab 2003; 88: 2185-2193.

21. Jääskeläinen J, Deneb A, Schwabe JW et al. Human androgen receptor gene ligand-binding-domain mutations leading to disrupted interaction between the $\mathrm{N}$-and C-terminal domains. J Mol Endocrinol 2006; 36: 361-368.

22. Hughes IA, Deeb A. Androgen resistance. Best Pract Res Clin Endocrinol Metab. 2006; 20: 577-598.

23. Kravarusic D, Seguier-Lipszyc E, Feigin E et al. Androgen insensitivity syndrome: Risk of malignancy and timing of surgery in a paediatric and adolescent population. Afr J Paediatr Surg 2011; 2: 194-198.

24. Nojima M, Taguchi T, Ando $\mathrm{Y}$ et al. Huge seminoma developed in a patient with testicular feminization. J Obstet Gynaecol Res 2004; 30: 109-112. 